\title{
Is the West best?: education for school information service professionals
}

\author{
JOE HALLEIN \\ Central Queensland University, Mackay Qld. Australia 4740
}

\begin{abstract}
School Library Educators in developing countries have, in the main, been training School Information Professionals using models of education developed in the United States and Europe. While there have been some local modifications to these westem models few countries have developed truly local education programs for Information Service Professionals. This is due, in part, to the fact that the Infomation Services that students are being educated to work with are global information services often based on services developed in the United States and Europe. Many of the advisers who helped to set up school library training programs are from Westem Countries and a large proportion of the staff lecturing in these programs have been educated in Westem Countries. The paper will conclude by discussing if westem models of education for School Information Service Professionals are the most appropriate models given the increased globilization of information services or whether locally developed models can best service the needs of those training to work in developing countries.
\end{abstract}

In developing countries, those individuals who are responsible for educating professional workers often face a problem of deciding between an education that meets the immediate needs of the society or one that will meet the future needs of the society. Choices must be made about whether to educate professionals at home or abroad, and whether their education should follow a western model, local model or some combination of the two. Educators of school library and information specialists have also needed to consider these questions.

Because there are great differences between developing countries with economics ranging from least developed countries with poor information inirastructure and high levels of illiteracy to the newly industrialized economies which are often producers of information technology, the library and information needs of these countries will differ and perhaps the education required for information professionals will also differ. There is also a difference in the level of information services required within a developing country with some urban sectors requiring the latest high technology infrastructure services while rural areas may still rely mainly on the oral transmission of information.

Information is increasingly becoming an international commodity. Satellite broadcasts of television across international borders, global telephone and computer networks enable people from all over the world to freely communicate. Yet, at the same time it might be impossible for the people in one region of a developing country to easily communicate with people in another part of the country. While there are about 50 telephones for every

Education for All: Culture, Reading and Information, IASL, 1998 
100 persons in the USA and Europe, there are only 4 per hundred in the Asian pacific region. This means that for much of the World effective telecommunications is not available for a majority of the population.

International organizations such as UNESCO and the Food and Agriculture Organisation (FAO) have developed information programs and activities which have an impact on the National Infrastructure of developing countries. These include:

- strengthening of information resources of selected library and information centers;

- provision of hardware and software to selected libraries and information centers;

- training of selected personnel in information systems, and applications of library and information services;

- introduction of norms and standards in information work such as cataloguing standards, vocabulary control and standard systems;

- formulation of national policy on information systems and services and mechanisms for their coordination;

- providing models for cooperation among libraries and information facilities for sharing information resources (Neelamegham 1994, p1 - 11)

A result of these efforts by the international agencies is that some information professionals in developing countries need to be educated to a level that will enable them to successfully implement these programs. The individuals chosen to receive this type of education will usually become the leading information professionals in their country and will have a great influence on the development of information services, including services to schools and on the education of those who will operate their services.

The technology used in the provision of information services is rapidly developing and changing. As Thai Library Educator, Chuitmau Sacchanand has said:

The most obvious generator of change in information science today is the computer. The 'information explosion' has happened as a result of technological improvements in storage and retrieval systems. This bodes well for the information scientist. Information specialists can supply information for research and development in all fields, but they need the training that permits to know the applications. They must have computer literacy; they must extend their control of data processing to ways and means not previously considered. Information specialists must learn to use the databases to their fullest potential. For all these, they need training. A related feature to this skill is that, as change takes place in the knowledge and technology of a given field of endeavor, so will changes appear in the ways information in the field is recorded and used. Rapid development and technological change not only characterize the information world, they shape it. (Sacchanand 1991,p302)

This required training in the effective use of computers is not really a local skill but rather an international skill since computer technology and programs are mostly designed to international standards. However information specialists in developing countries may need special education in how to make the best use of computers to meet the needs of the local population. 
The rapidly spreading Internet will have a global impact on information services. The Internet is based on systems developed in the USA and the language of the Internet is mainly English, the proportion being between 70 and 80 percent, information specialists in developing countries will need to be educated to effectively utilise the Internet to meet the information needs of the population of their country.

In 1898 Otto Von Bismark was asked what he felt was the most decisive factor in modern history he said "The fact that the North Americans Speak English" (Australian 4-5, 1997 P.22) It is estimated that 80 percent of information stored on computer world wide is in English. Do school information professionals need to be educated in English and if school information systems increasingly rely on the English language, what will happen to local language in schools? Will the school information service find itself divorced from the language of the local community it serves.

Relatively inexpensive CD ROMs of various data bases reference books available and are used throughout the developing world and these can be used even where the telecommunications facilities are poor but, of course, not when there is no electricity.

In Papua New Guinea the International schools, both secondary and primary, in urban areas are using CD ROMs in the school library yet the majority of schools in the country lack a collection of books. Again many school information specialists will need to be trained in the most effective searching techniques to be able to gain maximum value from their CD Roms.

Of course the acceptance of these new technologies can result in a new type of colonial imperialism. Rosario Gassol de Horawitz has observed that the "Commitment to technology means the acceptance of certain social structures and orientations. As a result, the introduction of technology into a developing country implies the adoption of certain values which might endanger existing values" (Gassol de Horawitz 1998, p16). Edward Lim the librarian at Australia's Monash University, has stated that about $85 \%$ of the worlds data bases are produced in either the United States or the European Community with the USA producing about three and half time those of the European community. Items included in the data bases are usually those which are deemed to be important in the producing country and may not be the most relevant to developing countries. Information specialists in developing countries will need to be aware of this and educated in techniques for shifting out the most relevant information for their countries needs if they are to provide useful information services.

Library and other information collections are usually catalogues and classified by one of the standard international classification systems. The education of information service professionals usually includes instruction in the use of one or more of these systems. According to an Information Specialist from Brunei nearly all the academic libraries in Southeast Asia, excluding Indonesia, use the Library of Congress Classification system to organize their book and non book collections (Simanjkuntak 1991) The library of Congress classification system was actually designed for a library to meet the unique

information needs of the members of the House of Representatives and the Senate of the United States. This means that librarians who have trained to use this system have learned a classification of knowledge and a hierarchy of this knowledge based on what was perceived best for the members of the US Congress. 
The major classification system from the USA that is in widespread use in schools is the Dewey Decimal systen. Under this system there is only one number for classifying all the various Malay languages 499.28, while English language can be classified in the whole range of numbers 420-429.50 English Language dictionary could be classified in 423, English Grammar 425 and Reading in English in 428 . The same is true for various other European languages. One wonders what kind of a view of the importance of their language that a speaker of Malay languages would get in a library using the Dewey Decimal system. Libraries around the world use these classification systems for administrative convenience because one can purchase catalogue records in these systems and cataloguing in publication data uses these systems and also for uniformity. However, the underlying cultural message behind these systems may not have been included in the librarian's education.

Of course in much of the developing world libraries and sophisticated information systems are not the main store house of knowledge. In much of Africa, for instance, oral tradition as passed on by storytellers, elders and priests in the main store of knowledge and information workers need to be able to tap into this source of knowledge if they are to operate effectively. Some programs for training information specialists do this, such as those offered by the University of Namibia. Students enrolled in teacher librarianship programs learn how to implement the "Basic Information skills Syllabus" which includes modules on developing information skills in schools which do not have book collections, students are taught to use oral resources, community leaders and elders and the community itself as an international resource. Western models of educating school information specialists usually operate on the assumption that the training will be at a University level. However, in many developing countries people studying to be primary school teachers enter teachers college after year 10 and they would not have the educational background to handle University level subjects. As part of the South Pacific region pilot project on school library development, UNESCO commissioned a group of Australian Library Educators to write a series of training modules for teachers who might use or run school libraries. These were written at a level that could be understood by someone with a grade 10 education and who had not done well enough in school to go on to grade 11 .

UNESCO which has been involved with information programs since its establishment became aware of the problem nations faced with the two traditions of information service, information to meet the global needs of science technology and commerce and international services to assist in a country's development while maintaining its cultural values and allowing individuals in the country to have access to a medium of social communication. Two different UNESCO programs were established, one UNISIST to promote the global access to scientific and technical information while the NATIS program was established to promote information as an essential part of the nations resources and to develop an informed society. These two programs were finally merged into UNESCOs General Information Programs (PGl) but the conflict between the two schools of thought still remain and this conflict is reflected in the various education programs for information specialists.

Should information specialists be educated to operate in the Global Information Network that is based on western culture and teaching or should they receive an education which reflects the values and traditions of their own society. One African Librarian has stated that: 
The concept of librarianship in Africa, the developing countries, or the Third World is not fundamentally different from that in the developed or other parts of the world, but often the differences, perhaps because they are unusual when seen out of their context, are over-emphasized and harped upon the neglect of the common bonds that unite all libraries in one world of librarianship and that the objectives also of libraries in Africa and the developing countries, along with other parts of the developed world, remain generally the same except that the accent in certain areas are more demanding and more pressing (Ogundipe 1994, p. 236)

This would imply that Librarians from developing countries would need the same basic education as those from developed countries, with perhaps some minor changes. However in other parts of the world a standard western curriculum in librarianship was not seen as satisfactory.

While Latin American programs in library education assumed the characteristics of the traditional core curriculum of the original postgraduate "bachelor's" program in library science in the United States, the world of professional practice, into which the graduates moved rapidly, involved them in a depressing dissolution of what they had learned. Libraries were few, and only the specialized or academic ones could use the skills of the newly fledged librarians. On the other hand, the education they had received did not equip them with the understanding and knowledge necessary to cope with the biggest challenge Third World librarians confront: providing the general population with the most elementary means for acquiring the information that would help them improve the quality of their life. To put it bluntly and simplistically, illiterates or functional illiterates do not use libraries (Gassol de Harowitz 1988, p3)

It seems that a curriculum based on one developed in the United States was not suitable for information workers in Latin America. Ogunshege says that for African information workers an additional objective needs to be included in their education programs which is to be able to improve literacy skills and the quality of life in rural areas where the majority of Africans live. Library schools in all countries would benefit from 'a close analysis of the information needs of rural society and its flow and transfer problems because some of these are pertinent to information transfer in developed countries, especially in such areas as providing literature for minority groups in urban areas, the literacy problems of immigrants an semiliteracy in low income areas of developed countries (Ogundipe 1994, p241).

It appears that education for information specialists in developing countries need to be able to train individuals for both local service needs as well as to be able to operate as part of the international information system. The curriculum would include the basic core curriculum of teaching librarianship that is offered by universities in the developed world with the addition of topics related to the needs of developing countries. These might include topics and as:

- General subject-related courses: sociology, rural demography, cultures of the world, human communications.

- Development courses: community development and information, agricultural information, cottage industries and business information, extension work, rural societies. 
- Knowledge: oral literature (as in various subject areas, eg religion, medicine, philosophy), oral history, oral traditions, including collection and recording techniques.

- Methodology for information transfer: dissemination and transfer, multimedia instructional approach-design techniques, etc, outreach and extension services, counselling and interviewing techniques. (Ogundipe 1994, p242)

It is interesting to note that students of library and information services from developing countries do not always rate the above topics as the most important. In a survey done of students from developing countries studying at schools of library and information services in the UK; the subjects studied that they found to be most useful when they returned to their own countries were Management, Computer Technology and Modern Information Technology and these three were also related as the most desirable to be included in training programs in their own countries (Keenan 1992, p. 291).

Should the education of information professionals be conducted in the students' own country or should it be conducted at overseas universities is a question often asked. At a 1993 seminar on information services held in Namibia it was recommended that 'Formal training at all levels should be provided by local institutions. Only when such training is not locally available, should opportunities be sought for study elsewhere. (Totlemyer, Loubser and Marais 1993, p223) The participants in Keenan's survey of overseas students study in the UK also felt that it would be best to provide most education in the students own country. Courses developed and offered in the students' own country can take local needs into account. For instance, the University of Namibia trains librarianship students to offer the basic information science course which is a compulsory school subject in grades $4-10$. This is a $\mathbf{1 4}$ module course on the effective use of information with the first five modules developed to be used by people living where there are no formal information agencies or even book collections. So students in 'tree schools' literally held under trees in Northern Namibia can learn about using local experts, story telling and elders as information sources; using 'natural' information sources, the radio as an information source and using the Bible, which is often the only printed source available, as an information resource. A unique program such as this would not be considered in the curriculum of overseas schools of library and information studies. At Srinakharinwirot University in Thailand, students study the ethics of providing information services to Thais, which would be different to that in say the USA or the UK. The author was engaged as a consultant by UNESCO to write and offer training programs for school information specialists in the South West Pacific. The course was originally designed to train individuals to run conventional libraries but when we offered the course in Vanuatu we realized that such libraries did not exist in most of the country. The focus of the course shifted to teaching information specialists to utilize local informal sources of information, to make basic information resources and to utilize programs such as story telling and readers theater to disseminate information.

Education programs for school information specialists are best offered in the student's own country or region, with only those taking highly specialized advanced courses studying overseas. The locally based courses need to offer training in all the core areas of school information service provision including the use of advanced information technology but they also need to include components on subjects such as providing literacy programs, 
making and utilizing appropriate educational resources, utilizing local communities and other topics suited to the provision of school information services in their own country. This education needs to be of world class standard because the offering of second class degrees and diplomas to be used in the developing world will only provide a disservice to future school information professionals.

\section{References}

The Australian (1987). January 4-5, 22.

Gassol de Horawitz, R. (1988). Librarianship: a third world perspective. New York: Greenwood Press.

Jacobs, V. (1993). The training of library and information personnel at the University of Namibia: present state and future prospects. In Co-ordination of information systems and services in Namibia (pp. 192-198). Windhoek Ministry of Education and Culture/University of Namibia.

Keenan, (1992). Brain train-professional education and training requirements in developing countries. Education for Information, 10, 287-297.

Neelamegham, A. (1994) Librarians and information services in developing countries: prospects and problems. In Papua New Cuinea Libraries Moresby. University of Papua New Guinea

Ogundipe, O.O. International and comparative librarianship in developing countries. Journal of Education for Library and Information Science, 35(2), 36-48.

Sacchanard, C. (1991). Library education and training for the new challenges in library and information services. In New Challenges in Library Services in the Developing World. National Library of Indonesia and the Indonesian Library Association, Jakarta.

Simandjuntak, S.H. (1991). Library of Congress Classification system: Its contribution to Southeast Asian academic libraries in general and the University of Brunei Darissalam in particular. In New Challenges in Library Services in the Developing World. Jakarta National Library of Indonesia and the Indonesian Library Association.

Totemeyer, A.J., Loubser, J., Marais, A.E., eds (1993). Coordination of Information Systems and Services in Namibia. Windhock Ministry of Education and Culture/University of Namibia. 